\title{
PENGARUH GAYA KEPEMIMPINAN PACESETTING TERHADAP MOTIVASI KERJA KARYAWAN F \& B SERVICE DEPARTMENT PADA SINTESA PENINSULA HOTEL MANADO
}

\author{
Betzy Girot $^{1 *}$, Bernadain D. Polii ${ }^{2}$, Seska Mengko ${ }^{3}$ \\ ${ }^{1}$ Murex Dive Resort, Kalasey Satu, Mandolang, Kab. Minahasa \\ ${ }^{2}$ Prodi D4 Manajemen Perhotelan, Jur. Pariwisata, Politeknik Negeri Manado \\ ${ }^{3}$ Prodi D3 Usaha Perjalanan Wisata, Jur. Pariwisata, Politeknik Negeri Manado \\ E-mail: betzy.girot15@gmail.com
}

\begin{abstract}
The Influence of Pacesetting Leadership Style on Work Motivation of Food and Beverage Service Department Employees at Sintesa Peninsula Hotel Manado. Employees with high work motivation will work with passion, discipline, initiative and with an awareness of their obligations to work more effectively and efficiently. With the existence of motivation, the thought, the attention, energy and activities of employees can be directed to reach the goals and objectives that are more useful and beneficial for the company and the employees themselves. High motivation in work can be achieved if it supported by a leadership style that is owned and applied by leaders in an organization or department. Leadership style applied by Food and Beverage Service Department leaders requires high standards of work and success, hopes that employees can follow the standard of work, but lack of appreciation that employees get in achieving their jobs, low employee freedom to take initiatives that will reduce challenges in the workplace, it has an impact on changes in work motivation of employees. Based on these problems, a study was conducted to determine whether the pacesetting leadership style had an effect on the work motivation of the employees of the Food and Beverage Service Department. This type of research is a quantitative study with a sample of 30 respondents. The results of the study stated that there is a strong influence of the Pacesetting Leadership Style variable on the Employee Work Motivation variable with a significance value of $0,000<0.05$ and $t$ count value of $5.360>t$ table 2.04841, obtained a correlation value of $r=0.712$ and the coefficient of determination $50.69 \%$, the rest $49.31 \%$ is influenced by other factors not examined. As an implication of the results of this study is that leaders need to provide the opportunities for employees to take the initiative in the work they do and be more flexible in each direction given so that employees are able to complete their work properly. To increase employee motivation, leaders need to inspire employees to work optimally, provide challenges in work, and be able to appreciate employees for work completed by employees.
\end{abstract}

Keywords: Leadership, pacesetting leadership style, work motivation

\begin{abstract}
Abstrak: Pengaruh Gaya Kepemimpinan Pacesetting terhadap Motivasi Kerja Karyawan Food and Beverage Service Department pada Sintesa Peninsula Hotel Manado. Karyawan dengan motivasi kerja tinggi akan bekerja dengan penuh gairah, disiplin, inisiatif dan dengan kesadaran akan kewajibannya untuk bekerja lebih efektif dan efisien. Dengan adanya motivasi, maka perhatian, pemikiran, tenaga dan kegiatan karyawan dapat di arahkan untuk tujuan dan sasaran yang lebih bermanfaat serta menguntungkan bagi perusahaan maupun karyawan itu sendiri. Motivasi yang tinggi dalam bekerja dapat tercapai apabila di dukung oleh gaya kepemimpinan yang dimiliki dan diterapkan oleh pemimpin dalam suatu organisasi atau departemen. Gaya Kepemimpinan yang diterapkan oleh pemimpin Food and Beverage Service Department menuntut standar kerja dan keberhasilan yang tinggi serta berharap para karyawan dapat mengikuti standar kerja tersebut, namun kurangnya apresiasi yang diperoleh karyawan dalam pencapaian pekerjaannya, rendahnya kebebasan karyawan untuk berinisiatif yang terntunya akan mengurangi tantangan didalam pekerjaan tersebut, hal ini tentu berdampak pada perubahan motivasi kerja para karyawan. Berdasarkan masalah tersebut kemudian diadakan penelitian untuk mengetahui apakah gaya kepemimpinan pacesetting berpengaruh terhadap motivasi kerja para karyawan Food and Beverage Service Department. Jenis penelitian yang digunakan adalah penelitian kuantitatif dengan sampel sebanyak 30 responden. Hasil penelitian menyatakan bahwa terdapat pengaruh yang kuat dari variabel Gaya Kepemimpinan Pacesetting terhadap variabel Motivasi Kerja Karyawan dengan nilai signifikansi sebesar $0,000<0,05$ dan nilai t hitung 5,360 $>\mathrm{t}$ tabel 2,04841, diperoleh nilai korelasi sebesar $\mathrm{r}=0,712$
\end{abstract}


dan nilai koefisien determinasi 50,69\%, selebihnya sebesar 49,31\% dipengaruhi oleh faktor-faktor lainnya yang tidak diteliti. Sebagai implikasi dari hasil penelitian ini adalah bahwa pemimpin perlu memberikan kesempatan bagi karyawan untuk berinisiatif dalam pekerjaan yang dilakukannya dan lebih fleksibel dalam setiap arahan yang diberikan sehingga karyawan mampu menyelesaikan pekerjaannya dengan baik. Untuk meningkatkan motivasi kerja karyawan maka pemimpin perlu untuk menginspirasi karyawan agar dapat bekerja dengan maksimal, memberikan tantangan dalam pekerjaan, dan sanggup mengapresiasi karyawan atas pekerjaan yang telah diselesaikan karyawan.

Kata Kunci: Kepemimpinan, gaya kepemimpinan pacesetting, motivasi kerja

Berbagai bidang khususnya kehidupan berorganisasi, faktor manusia merupakan masalah utama disetiap kegiatan yang ada didalamnya. Organisasi merupakan kesatuan sosial yang dikoordinasikan secara sadar dengan sebuah batasan yang reaktif dapat diidentifikasikan, bekerja secara terus menerus untuk mencapai tujuan (Robbins, 2006). Semua tindakan yang diambil dalam setiap kegiatan diprakarsai dan ditentukan oleh manusia yang menjadi anggota perusahaan. Perusahaan membutuhkan adanya faktor sumber daya manusia (SDM) yang berpotensial baik pemimpin maupun karyawan pada pola tugas dan pengawasan yang merupakan penentu tercapainya tujuan perusahaan. Sumber daya manusia (SDM) merupakan bagian terpenting dalam organisasi maupun perusahaan, oleh karena itu SDM harus dikelola dengan baik dan dibina secara cermat agar dapat memberikan keuntungan dan berkontribusi di perusahaan atau industri tempat mereka bekerja. Menggerakan SDM dalam perusahaan secara efektif tergantung pada bagaimana para pemimpin mampu memotivasi para karyawan untuk bekerja secara produktif. Sutikno (2014) mengemukakan bahwa kepemimpinan adalah kemampuan untuk mempengaruhi dan menggerakkan orang lain untuk mencapai tujuan. Kepemimpinan dalam organisasi diarahkan untuk mempengaruhi orang-orang yang dipimpinnya, agar mau berbuat seperti yang diharapkan ataupun diarahkan oleh orang yang memimpinnya. Pamela \& Oloko (2015) berpendapat bahwa motivasi adalah kunci dari organisasi yang sukses untuk menjaga kelangsungan pekerjaan dalam organisasi dengan cara dan bantuan yang kuat untuk bertahan hidup". Karyawan dengan motivasi kerja tinggi akan bekerja dengan penuh gairah, disiplin, inisiatif dan dengan kesadaran akan kewajibannya untuk bekerja lebih efektif dan efisien. Dengan adanya motivasi, maka perhatian, pemikiran, tenaga dan kegiatan karyawan dapat di arahkan untuk tujuan dan sasaran yang lebih bermanfaat serta menguntungkan bagi perusahaan maupun karyawan itu sendiri. Motivasi yang tinggi dalam bekerja dapat tercapai apabila di dukung oleh gaya kepemimpinan yang dimiliki dan diterapkan oleh pemimpin dalam suatu organisasi atau departemen. Salah satu faktor yang menentukan meningkatnya motivasi kerja karyawan adalah gaya kepemimpinan yang diterapkan di hotel dan departemen didalamnya. Hal ini diperkuat oleh Kartono (2011:93) yang mengatakan bahwa Gaya kepemimpinan mempunyai pengaruh yang kuat terhadap motivasi sebab keberhasilan seorang pemimpin dalam menggerakkan orang lain untuk mencapai suatu tujuan tergantung pada bagaimana pemimpin itu menciptakan motivasi di dalam diri karyawan. Tujuan penelitian ini adalah untuk mengukur dan menganalisis apakah gaya kepemimpinan pacesetting berpengaruh terhadap motivasi kerja para karyawan Food and Beverage Service Department"

\section{Pengertian Food and Beverage Department}

Food and Beverage department di dalam industri perhotelan merupakan salah satu departemen yang berperan penting dalam kelangsungan operasional karena produk yang ditawarkan/dijual kepada tamu adalah produk yang menyangkut kebutuhan tamu sehari-harinya, yaitu produk makanan dan minuman. Menurut Soekarno dan Pendit (1998:4) menyebutkan bahwa "Food and Beverage Department merupakan bagian dari hotel yang mengurus dan bertanggung jawab terhadap kebutuhan pelayanan makanan dan minuman serta kebutuhan lain yang terkait, dari para tamu yang tinggal maupun yang tidak tinggal di hotel tersebut dan dikelola secara komersial serta profesional". Dalam menjalankan tugasnya, $F \& B$ department terbagi menjadi dua bagian 
yang saling bergantung satu sama lain, diantaranya: 1) F \& B bagian depan (front service) yaitu bagian yang langsung berhubungan dengan tamu, terdiri dari bar, restaurant, banquet dan room service; 2) F \& B bagian belakang (back service) yaitu bagian yang tidak langsung berhubungan dengan tamu karena harus melalui perantara pramusaji, terdiri dari kitchen dan stewarding. Dari penjelasan diatas maka dapat disimpulkan bahwa Food \& Beverage Department adalah salah satu bagian penting yang ada di setiap hotel dimana bagian tersebut yang bertanggung jawab atas ketersediaan dan pelayanan makan dan minum bagi tamu inhouse dan non-inhouse yang dikelola secara komersial guna meningkatkan pendapatan hotel.

\section{Motivasi Kerja}

Secara harafiah, istilah motivasi berasal dari kata latin "movere", yang berarti bergerak yang menunjukan suatu proses yang dimulai dengan defisiensi fisiologis atau psikologis yang menggerakkan perilaku atau dorongan yang ditunjukan untuk tujuan atau insentif, sehingga untuk memahami proses motivasi bergantung pada pengertian dan hubungan antara kebutuhan, dorongan, dan insentif (Luthans, 2005). Menurut Hasibuan (2016: 219), motivasi kerja adalah pemberian daya penggerak yang menciptakan kegairahan kerja seseorang agar mereka mau bekerja sama, bekerja efektif, dan terintegrasi dengan segala daya upayanya untuk mencapai kepuasan. Chukwuma \& Obiefuna (2014) mengatakan "Motivasi kerja adalah proses membangkitkan perilaku, mempertahankan kemajuan perilaku, dan menyalurkan perilaku tindakan yang spesifik. Dengan demikian, motif (kebutuhan, keinginan) mendorong karyawan untuk bertindak. Motivasi kerja adalah suatu yang menimbulkan semangat atau dorongan kerja. Oleh sebab itu, motivasi kerja dalam psikologi kerja biasa disebut pendorong semangat kerja (Anoraga, 2009). Setiawan (2015) juga mengemukakan bahwa motivasi kerja adalah sesuatu yang menimbulkan semangat atau dorongan kerja. Oleh sebab itu motivasi kerja biasa disebut pendorong semangat kerja. Dari beberapa pengertian diatas maka dapat dibuat kesimpulan bahwa motivasi kerja adalah daya dorong atau daya gerak yang membangkitkan dan mengarahkan perilaku karyawan pada suatu perbuatan atau pekerjaan pada upaya-upaya nyata untuk mencapai tujuan yang telah ditetapkan. Indikator yang terdapat pada motivasi kerja adalah gairah dalam bekerja, daya penggerak dalam bekerja dan pendorong karyawan dalam bertindak. Jenis-jenis motivasi kerja dapat dikelompokkan menjadi dua jenis menurut Hasibuan (2007) yaitu: 1) Motivasi kerja positif (insentif positif), manajer memotivasi bawahan dengan memberikan hadiah kepada mereka yang berprestasi baik. Dengan motivasi positif ini semangat kerja bawahan akan meningkat, karena manusia pada umumnya senang menerima yang baikbaik saja; 2) Motivasi kerja negatif (insentif negatif), manajer memotivasi bawahan dengan memberikan hukuman kepada mereka yang pekerjannya kurang baik (prestasi rendah). Dengan memotivasi negatif ini semangat kerja bawahan dalam waktu pendek akan meningkat, karena takut dihukum. Dalam prakteknya, kedua jenis motivasi kerja ini yang peling sering digunakan oleh suatu perusahaan, penggunaanya pun harus tepat dan seimbang, agar dapat meningkatkan semangat karyawan.

\section{Model Motivasi Kerja}

Ada beberapa konsep model motivasi kerja yang disampaikan dalam buku Hasibuan (2013:148) sebagai berikut:

1) Model Tradisional, model ini mengemukakan bahwa untuk memotivasi bawahan agar gairah kerjanya meningkat, perlu diterapkan sistem insentif, yaitu pemberian insentif uang atau barang kepada karyawan yang berprestasi baik.

2) Model Hubungan Manusia, model ini mengemukakan bahwa untuk memotivasi bawahan agar gairah kerjanya meningkat ialah dengan mengakui kebutuhan sosial mereka dan membuat mereka merasa berguna dan penting. 
3) Model Sumber Daya Manusia, model ini mengatakan bahwa karyawan dimotivasi oleh banyak faktor, bukan hanya uang dan barang atau keinginan akan kepuasan, tetapi juga kebutuhan akan pencapaian dan pekerjaan yang berarti.

\section{Konsep Kepemimpinan}

Teori kepemimpinan merupakan topik yang paling populer dalam beberapa tahun belakangan ini, dimana teori ini telah mendapat perhatian yang cukup besar dari semua kalangan di seluruh penjuru dunia, baik dari kalangan professional, pebisnis, akademisi, dan birokrasi/pemerintahan. Hal tersebut dapat dilihat dari banyaknya para peneliti serta para ahli untuk melakukan penelitian tentang gaya, sifat dan perilaku kepemimpinan. Dengan adanya keragaman tersebut, berdampak kepada banyaknya pendapat untuk mendefinisikan pemimpin. Menurut Kartono (2010:18), pemimpin adalah seorang pribadi yang memiliki kecakapan dan kelebihan, khususnya kecakapan dan kelebihan di satu bidang sehingga dia mampu mempengaruhi orang lain untuk bersamasama melakukan aktivitas-aktivitas tertentu demi pencapaian satu atau beberapa tujuan. McShane dan Von Glinow (2010) menyatakan kepemimpinan adalah tentang mempengaruhi, memotivasi, dan memungkinkan ornag lain memberikan kontribusi ke arah efektivitas dan keberhasilan organisasi di mana mereka menjadi anggotanya. Menurut Fahmi (2016) kepemimpinan adalah suatu ilmu yang mengkaji secara komprehensif mempengaruhi, mengarahkan, mengawasi orang lain untuk mengerjakan tugas sesuai dengan perintah yang diperintahkan. Kepemimpinan adalah kemampuan mempengaruhi orang yang mengarah kepada pencapaian tujuan. Dari beberapa pemaparan tentang pengertian kepemimpinan diatas, maka dapat ditarik kesimpulan bahwa kepemimpinan adalah kemampuan seorang pemimpin untuk melibatkan orang lain, sekelompok orang atau organisasi dalam mencapai tujuannya dengan cara mempengaruhi dan mengarahkan orang-orang tersebut.

\section{Konsep Gaya Kepemimpinan}

Setiap pemimpin memiliki cara/gaya/tipe yang berbeda-beda antara yang satu dengan yang lain dalam memimpin suatu organisasi ataun perusahaan. Perilaku pemimpin merupakan hal yang dapat dipelajari dan dilatih agar menjadi pemimpin yang efektif. Kepemimpinan adalah sekumpulan ciri yang digunakan pimpinan untuk mempengaruhi bawahan agar sasaran organisasi tercapai atau dapat pula dikatakan bahwa gaya kepemimpinan adalah pola perilaku dan strategi yang disukai dan sering diterapkan oleh seorang pimpinan. Gaya kepemimpinan adalah cara seorang pemimpin mempengaruhi perilaku bawahan, agar mau bekerja sama dan bekerja secara produktif untuk mencapai tujuan organisasi. Kemudian Molan (2011) gaya kepemimpinan adalah kemampuan individu untuk mempengaruhi, memotivasi dan membuat orang lain mampu memberikan kontribusinya demi efektivitas dan keberhasilan organisasi. Berdasarkan definisi beberapa ahli diatas dapat disimpulkan bahwa gaya kepemimpinan adalah suatu cara pemimpin untuk mempengaruhi bawahannya agar dapat bekerja sama dan bekerja secara produktif untuk mencapai tujuan organisasi.

\section{Kepemimpinan Pacesetting Leadership (Penentu Kecepatan)}

Salah satu gaya kepemimpinana berbasis emotional intelligence adalah gaya Kepemimpinan Penentu Kecepatan (Pacesetting Leadership). Marchewka (2015) menjelaskan bahwa pacesetting leadership style adalah "Seorang pemimpin yang menetapkan standar tinggi dalam pelaksanaan pekerjaan dan memiliki sikap kerjakan apa yang saya kerjakan sekarang". Pemimpin jenis ini cenderung ingin pekerjaannya diselesaikan sebaik mungkin dengan waktu sesingkat mungkin, sehingga pekerja dengan performa kerja rendah dapat dengan cepat diidentifikasi dan diganti bila tidak memenuhi standar, karena gaya ini adalah gaya yang melibatkan dorongan untuk mencapai inisiatif, dan dorongan untuk mencapai hasil. Menurut Goleman (2003) gaya kepemimpinan penentu kecepatan adalah gaya yang menuntut 
keberhasilan dan kesempurnaan dari tugas yang diberikan kepada bawahannya. Pemimpin dengan gaya ini memiliki tujuan yang jelas mengenai hal-hal yang boleh dan tidak boleh dikerjakan. Gaya kepemimpinan penentu kecepatan menetapkan standar kerja yang tinggi untuk diri mereka sendiri dan orang yang mereka pimpin. Salah satu atribut kunci dari gaya ini adalah pendekatan memimpin dengan contoh. Kepemimpinan ini tidak meminta pengikut/bawahan mereka untuk melakukan sesuatu yang tidak akan mereka lakukan sendiri. Gaya kepemimpinan penentu kecepatan tidak memberi karyawan banyak umpan balik positif namun di sisi lain pemimpin dengan gaya kepemimpinan ini tidak memiliki masalah melompat masuk dan mengambil alih jika pemimpin tersebut berpikir kemajuan suatu pekerjaan terlalu lambat. Salah satu kelebihan gaya kepemimpinan penentu kecepatan adalah mereka dengan cepat mencapai hasil bisnis. Dalam jangka pendek, akan ada kelompok berenergi tinggi dengan kinerja luar biasa dalam hal menyelesaikan tugas serta kualitas pekerjaan itu sendiri. Gaya kepemimpinan penentu kecepatan juga memiliki efek negatif karena seringkali karyawan hanya diliputi oleh kecepatan dan tuntutan yang diberikan kepada mereka, menghasilkan moral yang cepat memburuk. Ironisnya, pemimpin tidak memiliki kesabaran untuk mereka yang perlu belajar, atau tidak mengambil pekerjaan baru dengan cukup cepat. Cara paling efektif untuk menggunakan gaya penentu kecepatan adalah ketika sebuah bisnis atau departemen membutuhkan hasil cepat dari kelompok yang sudah sangat termotivasi dan kompeten. Ini berarti motivasi yang mendorong pemimpin juga harus ada diantara para pengikut. Gaya ini juga efektif ketika anggota kelompok sangat kompeten dalam tugas yang akan mereka selesaikan, anggota kelompok akan diminta untuk bekerja dengan cepat. Tidak ada waktu untuk belajar ditempat kerja, atau mengajarkan seseorang keterampilan yang mungkin tidak mereka miliki. Sementara gaya penentu kecepatan bisa sangat efektif dalam mendapatkan hasil dalam jangka pendek, itu bukan gaya yang dapat digunakan dalam jangka panjang. Sejujurnya, penentu kecepatan hebat dalam membakar semangat rekan kerja mereka. Gaya kepemimpinan penentu kecepatan bisa sangat efektif jika digunakan dengan hemat; ketika itu benar-benar dibutuhkan untuk kebaikan bisnis. Menurut Masaong (2011) gaya kepemimpinan pacesetting juga adalah gaya kepemimpinan yang dimiliki oleh seorang pemimpin yang menuntut keberhasilan dan kesempurnaan dari tugas yang diberikan kepada bawahannya, bersikap obsesif bahwa segala sesuatu bisa dilakukan dengan lebih baik, lebih cepat sehingga meminta hal yang sama pada semua bawahannya, cepat menunjuk staf yang kinerjanya buruk dan melakukan perbaikan secara terus menerus, jika staf tidak melakukannya dengan baik, pemimpin itu sendiri yang akan menunjuk orang lain yang mampu untuk menggantikan pekerjaan tersebut dan memberikan arahan yang terperinci dan tidak fleksibel. Pacesetting leadership style merupakan kepemimpinan yang berfokus pada realisasi dari aktivitas yang kompleks. Para pemimpin biasanya menyerahkan kepada karyawan contoh perilaku yang diinginkan. Mereka ingin karyawan bekerja keras seperti mereka dan terobsesi dengan ide-ide untuk meningkatkan dan mempercepat alur kerja. Pacesetting leadership adalah "kepemimpinan yang langsung mengidentifikasi pekerja malas dan segera mencari pengganti mereka. Pengganti, tidak selalu memberi kesempatan untuk meningkatkan status mereka sendiri. Seringkali, seorang manajer tidak dapat dengan jelas menyatakan tujuan dan persyaratan strategis untuk personel, percaya bahwa yang terakhir harus sudah tahu segalanya di bidang tertentu. Kalau tidak, ada baiknya mempertimbangkan pemberhentian mereka. Pacesetting leadership berfokus pada target dan kecepatan pencapaian target tersebut. Mereka menetapkan standar dan jadwal kinerja bagi tim untuk mencapai tujuan dan mendapatkan hasil terbaik. Para pemimpin yang menetapkan kecepatan biasanya memastikan pekerjaan selesai sesuai jadwal dan mencapai tujuan dengan cepat. Kelemahan terbesar dari pengaturan kecepatan adalah terlalu mudah diprediksi. Banyak pemimpin penentu kecepatan membanjiri anggota tim dengan tenggat waktu, dan merusak kreativitas mereka saat mereka bergegas menyelesaikan pekerjaan mereka. Akibatnya, gaya ini bekerja paling baik ketika karyawan memiliki motivasi tinggi dan sudah menjadi pekerja yang kompeten. Ini juga bagus 
jika jadwal yang jelas perlu ditetapkan untuk serangkaian tugas tertentu. Berdasarkan pendapat para ahli maka dapat disintesiskan gaya kepemimpinan pacesetting adalah gaya kepemimpinan yang mencontohkan dirinya untuk suatu kesempurnaan dan keberhasilan dalam tugas dengan alur kerja yang cepat. Dengan indikator penelitian adalah, standar kerja tinggi, kecepatan penyelesaian kerja, pemberian contoh, perbaikan terus menerus, penunjukkan karyawan yang lebih kompeten, pemimpin turun tangan mengambil alih pekerjaan apabila dinilai pekerjaan tidak kunjung selesai, tegas pada bawahan, memberi arahan terperinci, tidak fleksibel, tidak ada inisiatif bawahan.

\section{Kerangka Berpikir}

Pemimpin harus mampu memberikan motivasi yang baik kepada anak buahnya. Berilah kepada anggota-anggota kelompok atau bawahan satu motivasi atau satu kompleks motif-motif tertentu, maka pasti mereka bersedia melakukan perbuatan-perbuatan besar atau perbuatan kepahlawanan lainnya. Karena itulah gaya kepemimpinan mempunyai pengaruh yang kuat terhadap motivasi sebab keberhasilan seorang pemimpin dalam menggerakkan orang lain untuk mencapai suatu tujuan tergantung pada bagaimana pemimpin itu menciptakan motivasi di dalam diri karyawan. Salah satu atribut kunci dari gaya kepemimpinan pacesetting ini adalah pendekatan memimpin dengan contoh yang artinya pemimpin dapat memberi contoh kepada karyawan tentang bagaimana melakukan pekerjaan dengan standar kerja yang dimiliki oleh pemimpin, sehingga karyawan akan termotivasi untuk memiliki gairah kerja yang sama seperti pimpinan.. Pacesetting leadership berfokus pada target dan kecepatan pencapaian target tersebut, hal ini dapat menjadi pendorong bagi karyawan untuk bekerja lebih giat lagi dalam mencapai target. Jadi dapat diasumsikan bahwa gaya kepemimpinan pacesetting adalah salah satu faktor yang dapat mempengaruhi motivasi kerja karyawan. Berdasarkan teori-teori yang telah dikembangkan tersebut dan untuk memperjelas kerangka pemikiran yang dimaksud oleh peneliti dalam penelitian ini dapat dilihat dalam gambar berikut ini :

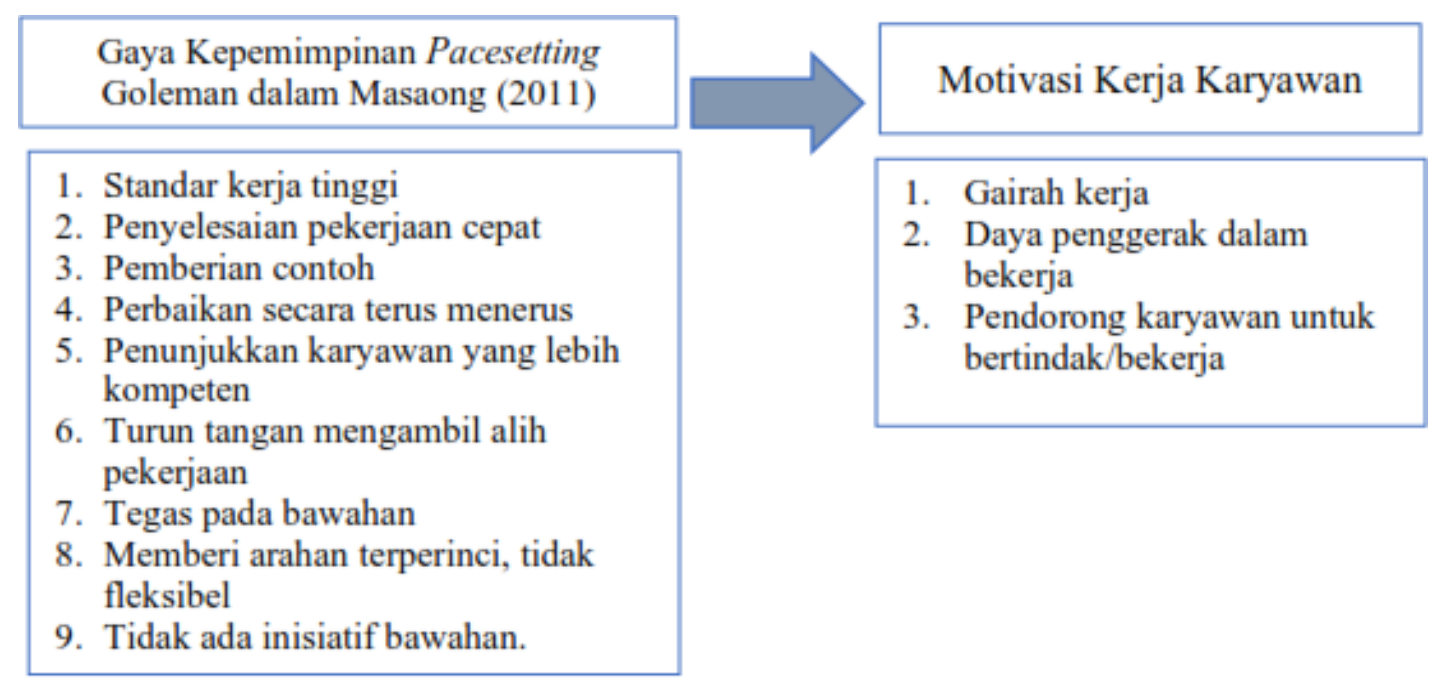

Gambar 1: Model Penelitian

\section{Hipotesis}

Hipotesis dalam penelitian ini adalah gaya kepemimpinan pacesetting yang diterapkan seorang pemimpin memiliki pengaruh terhadap motivasi kerja staff/karyawan Food and Beverage Service Department pada Sintesa Peninsula Hotel Manado. 


\section{Hubungan Antar Variabel}

Gaya kepemimpinan mempunyai pengaruh yang kuat terhadap motivasi kerja karyawan, sebab keberhasilan seorang pemimpin dalam menggerakkan orang lain untuk mencapai suatu tujuan tergantung pada bagaimana pemimpin itu menciptakan motivasi di dalam diri setiap karyawan (Kartono, 2011). Pemimpin berusaha mempengaruhi atau memotivasi bawahannya agar dapat bekerja sesuai dengan tujuan yang diharapkan pemimpin. Tugas seorang pemimpin yang utama dalam perusahaan memberikan sumbangan yang besar berupa tenaga dan pikiran terhadap perusahaannya agar tujuan perusahaan dapat tercapai. Tidak semua orang dapat melaksanakan gaya kepemimpinan yang baik, karena tugas-tugas dalam strategi kepemimpinan menunntut suatu tanggung jawab yang besar. Selain daripada itu, untuk menimbulkan motivasi kerja yang tinggi, dibutuhkan suatu tindakan yang tepat kepada karyawan di suatu perusahaan. Dan tindakan tersebut berasal dari pemimpin atau yang biasa disebut dengan gaya kepemimpinan. Gaya kepemimpinan pacesetting diasumsikan memiliki pengaruh yang kuat terhadap motivasi kerja karyawan. Pemimpin yang mencontohkan dirinya untuk suatu keberhasilan dan kesempunaan tugas dapat memotivasi karyawan untuk memiliki gairah dalam bekerja untuk mencapai tujuan. Setiap pemimpin mengetahui secara jelas tentang apa yang dapat memotivasi karyawan dalam bekerja agar mereka bisa berinteraksi secara efektif.

\section{METODE}

Jenis penelitian yang digunakan pada penelitian ini adalah penelitian kuantitatif dengan pendekatan deskripti bertujuan untuk mendeskripsikan objek penelitian ataupun hasil penelitian yang berfungsi untuk mendeskripsikan atau memberi gambaran terhadap objek yang diteliti melalui data atau sampel yang telah terkumpul sebagaimana adanya, tanpa melakukan analisis dan membuat kesimpulan yang berlaku umum. Populasi dalam penelitian ini adalah seluruh karyawan yang ada di $F \& B$ Service Department Sintesa Peninsula Hotel Manado yang berjumlah 30 orang. Penelitian ini menggunakan penulis penarikan sample dengan teknik sampling jenuh dimana semua anggota populasi dijadikan sampel. Dalam penelitian jumlah sampel yang penulis ambil sebanyak 30, dimana jumlah populasi sama dengan jumlah sampel. Pengumpulan data primer yang ada dalam penelitian ini menggunakan survei dalam bentuk kuesioner mengenai tanggapan responden tentang pengaruh gaya kepemimpinan terhadap motivasi kerja staff $F \& B$ Service Department pada Sintesa Peninsula Hotel Manado.Data sekunder yang digunakan yaitu data yang sudah diolah oleh instansi atau perusahaan seperti sejarah dan struktur organisasi Sintesa Peninsula Hotel Manado Metode pengumpulan data yang digunakan dalam penelitian ini adalah survei dengan kuesioner (daftar pertanyaan) serta studi pustaka merupakan metode pengumpulan data yang dilakukan dengan membaca buku-buku, literatur, jurnal-jurnal, referensi yang berkaitan dengan penelitian ini dan penelitian terdahulu yang berkaitan dengan penelitian yang sedang dilakukan.

Variabel dalam penelitian ini terdiri dari dua variabel yaitu gaya kepemimpinan pacesetting sebagai variabel independen (variabel $\mathrm{X}$ ) dan motivasi kerja staff $F \& B$ Service Department sebagai variabel dependen (variabel Y) dengan menggunakan skali likert. Penelitian ini akan menggunakan tiga (3) teknik statistik untuk mengukur, mengkaji dan mengetahui pengaruh yang melibatkan dua variabel yaitu pengaruh gaya kepemimpinan Pacesetting terhadap motivasi kerja karyawan $F \& B$ Service department Sintesa Peninsula Manando. Analisis regresi linear sederhana digunakan untuk memprediksi nilai koefisien regresi dari masing-masing variabel dalam penelitian, yakni Motivasi Kerja Karyawan (Variabel Y) jika Gaya Kepemimpinan Pacesetting (Variabel X) akan dinaikkan atau diturunkan. Sugiyono (2010) menyatakan persamaan matematis regresi sederhana menggunakan rumus sebagai berikut: $Y=$ $a+b X+e$ 
Keterangan:

$\mathrm{Y} \quad=$ Motivasi Kerja Karyawan

a $\quad$ Konstanta

$\mathrm{b} \quad=$ Koefisien Regresi Motivasi Kerja Karyawan

$\mathrm{X} \quad=$ Gaya Kepemimpinan Pacesetting

e $\quad=$ standart error sebesar $5 \%$

Untuk menghitung a dan $\mathrm{b}$ maka digunakan rumus:

$a=\frac{\left(\sum y\right)\left(\sum x^{2}\right)-\left(\sum x\right)\left(\sum x y\right)}{n\left(\sum x^{2}\right)-\left(\sum x\right)^{2}}$

$b=\frac{n\left(\sum x y\right)-\left(\sum x\right)\left(\sum y\right)}{n\left(\sum x^{2}\right)-\left(\sum x\right)^{2}}$

Koefisien korelasi adalah indeks atau bilangan yang digunakan untuk mengukur derajat hubungan, meliputi kekuatan hubungan dan bentuk/arah hubungan. Untuk kekuatan hubungan, nilai koefisien korelasi berada di antara -1 dan +1 . Untuk bentuk/arah hubungan, nilai koefisien korelasi dinyatakan dalam positif (+) dan negatif $(-)$, atau $(-1 \leq \mathrm{KK} \leq+1)$. Persamaan koefisien korelasi (r) ditentukan sebagai berikut :

$$
r=\frac{n\left(\sum X Y\right)-\left(\sum X\right)\left(\sum Y\right)}{\sqrt{\left[n \sum X^{2}-\left(\sum X\right)^{2}\right]\left[n \sum Y^{2}-\left(\sum Y\right)^{2}\right]}}
$$

Dengan penjelasan sebagai berikut:

$\mathrm{r} \quad=$ koefisien korelasi Pearson

$\mathrm{X} \quad=$ variabel bebas

$\mathrm{Y} \quad=$ variabel terikat

$\mathrm{n} \quad=$ jumlah sampel

\section{HASIL DAN PEMBAHASAN}

1. Tanggapan responden terhadap gaya kepemimpinan pacesetting (Variabel X) di Food and Beverage Service Department

Berikut merupakan hasil kuesioner tanggapan responden mengenai Gaya Kepemimpinan Pacesetting di FBS Department.

Tabel 2 dapat dijelaskan jawaban responden berdasarkan item-item pernyataan tentang Gaya Kepemimpinan Pacesetting (Variabel X)

1) Dari 30 responden yang memberikan tanggapan atas pernyataan tentang pemimpin berpegang teguh pada standar kerja yang tinggi, sebanyak $12(40 \%)$ responden menyatakan sangat setuju, $16(53 \%)$ responden menyatakan setuju dan $2(7 \%)$ responden menyatakan ragu-ragu.

2) Dari 30 responden yang memberikan tanggapan atas pernyataan pemimpin melaksanakan standar kerja yang tinggi, sebanyak $10(33 \%)$ responden menyatakan sangat setuju, 17 $(57 \%)$ responden menyatakan setuju dan $3(10 \%)$ responden menyatakan ragu-ragu.

3) Dari 30 responden yang memberikan tanggapan atas pernyataan pemimpin berharap segala sesuatu bisa dikerjakan oleh karyawan dengan lebih baik dan lebih cepat, sebanyak $14(47 \%)$ responden menyatakan sangat setuju, 12 (40\%), responden menyatakan setuju dan $4(13 \%)$ responden menyatakan ragu-ragu.

4) Dari 30 responden yang memberikan tanggapan atas pernyataan bawahan diberikan contoh dan melakukan perbaikan secara terus menerus, sebanyak $11(37 \%)$ responden menyatakan sangat setuju, $15(50 \%)$ responden menyatakan setuju dan $4(13 \%)$ responden menyatakan ragu-ragu. 
Tabel 2: Tanggapan responden mengenai Gaya Kepemimpinan Pacesetting

\begin{tabular}{|c|c|c|c|c|c|c|c|c|c|c|c|c|}
\hline \multirow{3}{*}{ No } & \multicolumn{11}{|c|}{ Jawaban Responden } & \multirow{3}{*}{ Jumlah } \\
\hline & \multirow{2}{*}{ Butir Soal } & \multicolumn{2}{|c|}{$\mathrm{SS}$} & \multicolumn{2}{|c|}{$\underline{\mathrm{S}}$} & \multicolumn{2}{|c|}{$\underline{\mathrm{RR}}$} & \multicolumn{2}{|c|}{$\underline{\mathrm{TS}}$} & \multicolumn{2}{|c|}{ STS } & \\
\hline & & $\mathrm{F}$ & $\%$ & $\mathrm{~F}$ & $\%$ & $\mathrm{~F}$ & $\%$ & $\mathrm{~F}$ & $\%$ & $\mathrm{~F}$ & $\%$ & \\
\hline 1 & $\mathrm{X} 1$ & 12 & 40 & 16 & 53 & 2 & 7 & - & - & - & - & 30 \\
\hline 2 & $\mathrm{X} 2$ & 10 & 33 & 17 & 57 & 3 & 10 & - & - & - & - & 30 \\
\hline 3 & X3 & 14 & 47 & 12 & 40 & 4 & 13 & - & - & - & - & 30 \\
\hline 4 & $\mathrm{X} 4$ & 11 & 37 & 15 & 50 & 4 & 13 & - & - & - & - & 30 \\
\hline 5 & $\mathrm{X} 5$ & 7 & 23 & 10 & 33 & 12 & 40 & 1 & 3 & - & - & 30 \\
\hline 6 & X6 & 7 & 23 & 11 & 37 & 9 & 30 & 3 & 10 & - & - & 30 \\
\hline 7 & $\mathrm{X7}$ & 11 & 37 & 15 & 50 & 4 & 13 & - & - & - & - & 30 \\
\hline 8 & $\mathrm{X} 8$ & 14 & 47 & 11 & 37 & 5 & 17 & - & - & - & - & 30 \\
\hline 9 & X9 & - & - & 15 & 50 & 12 & 40 & 3 & 10 & - & - & 30 \\
\hline 10 & X10 & 1 & 3 & 12 & 40 & 12 & 40 & 5 & 17 & - & - & 30 \\
\hline & TOTAL & 87 & $29 \%$ & 134 & $45 \%$ & 67 & $22 \%$ & 12 & $4 \%$ & - & $0 \%$ & 300 \\
\hline
\end{tabular}

Sumber: Data Olahan 2019

5) Dari 30 responden yang memberikan tanggapan atas pernyataan pemimpin akan turun tangan/mengambil alih pekerjaan apabila karyawan tidak mampu mengerjakannya dengan baik, sebanyak $7(23 \%)$ responden menyatakan sangat setuju, $10(33 \%)$ responden menyatakan setuju dan $12(40 \%)$ responden menyatakan ragu-ragu dan $1(3 \%)$ responden menyatakan tidak setuju.

6) Dari 30 responden yang memberikan tanggapan atas pernyataan pemimpin akan menunjuk karyawan lain untuk menyelesaikan pekerjaan yang tidak dapat diselesaikan oleh karyawan, sebanyak $7(23 \%)$ responden menyatakan sangat setuju, $11(36 \%)$ responden menyatakan setuju dan $9(30 \%)$ responden menyatakan ragu-ragu dan 3 (10 $\%)$ responden menyatakan tidak setuju.

7) Dari 30 responden yang memberikan tanggapan atas pernyataan pemimpin tegas terhadap bawahan yang memiliki kinerja kurang baik/ tidak baik, sebanyak 11 (37\%) responden menyatakan sangat setuju, $15(50 \%)$ responden menyatakan setuju dan 4 (13\%) responden menyatakan ragu-ragu.

8) Dari 30 responden yang memberikan tanggapan atas pernyataan pemimpin memberi arahan secara terperinci dan jelas dalam pekerjaan, sebanyak $14(46 \%)$ responden menyatakan sangat setuju, 11 (37\%) responden menyatakan setuju dan $5(17 \%)$ responden menyatakan ragu-ragu.

9) Dari 30 responden yang memberikan tanggapan atas pernyataan setiap arahan yang diberikan pemimpin bersifat tidak fleksibel, sebanyak $15(50 \%)$ responden menyatakan setuju, 12 (40\%) responden menyatakan ragu-ragu, dan $3(10 \%)$ responden menyatakan tidak setuju.

10) Dari 30 responden yang memberikan tanggapan atas pernyataan Pemimpin tidak memberi kebebasan untuk berinisiatif dari bawahan, sebanyak 1 (33\%) responden menyatakan sangat setuju, $12(40 \%)$ responden menyatakan setuju, $12(40 \%)$ responden menyatakan ragu-ragu, dan $5(17 \%)$ responden menyatakan tidak setuju.

\section{Tanggapan Responden Terhadap Motivasi Kerja Karyawan di Food and Beverage Service Department}

Berdasarkan data yang terkumpul dari kuesioner tentang motivasi kerja karyawan, yang ditampilkan dalam bentuk Tabel 3 berikut ini: 
Tabel 3: Tanggapan Responden Terhadap Motivasi Kerja Karyawan

\begin{tabular}{|c|c|c|c|c|c|c|c|c|c|c|c|c|}
\hline \multirow{3}{*}{ No. } & \multirow{3}{*}{ Butir soal } & \multicolumn{10}{|c|}{ Jawaban Responden } & \multirow{3}{*}{ Jumlah } \\
\hline & & \multicolumn{2}{|c|}{ SS } & \multicolumn{2}{|c|}{$\mathrm{S}$} & \multicolumn{2}{|c|}{$\mathrm{RR}$} & \multicolumn{2}{|c|}{$\mathrm{TS}$} & \multicolumn{2}{|c|}{ STS } & \\
\hline & & $\mathrm{F}$ & $\%$ & $\mathrm{~F}$ & $\%$ & $\mathrm{~F}$ & $\%$ & $\mathrm{~F}$ & $\%$ & $\mathrm{~F}$ & $\%$ & \\
\hline 1 & Y1 & 22 & 73 & 7 & 23 & 1 & 3 & - & - & - & - & 30 \\
\hline 2 & Y2 & 15 & 50 & 9 & 30 & 6 & 20 & - & - & - & - & 30 \\
\hline 3 & Y3 & 8 & 27 & 10 & 33 & 11 & 37 & 1 & 3 & - & - & 30 \\
\hline 4 & Y4 & 18 & 60 & 11 & 37 & 1 & 3 & - & - & - & - & 30 \\
\hline 5 & Y5 & 12 & 40 & 16 & 53 & 2 & 7 & - & - & - & - & 30 \\
\hline 6 & Y6 & 15 & 50 & 15 & 50 & - & - & - & - & - & - & 30 \\
\hline 7 & Y7 & 16 & 53 & 13 & 43 & 1 & 3 & - & - & - & - & 30 \\
\hline 8 & Y8 & 7 & 23 & 9 & 30 & 13 & 43 & 1 & 3 & - & - & 30 \\
\hline 9 & Y9 & 13 & 43 & 13 & 43 & 3 & 10 & 1 & 3 & - & - & 30 \\
\hline 10 & Y10 & 17 & 57 & 13 & 43 & - & - & - & - & - & - & 30 \\
\hline 11 & Y11 & 16 & 53 & 13 & 43 & 1 & 3 & - & - & - & - & 30 \\
\hline 12 & Y12 & 12 & 40 & 14 & 47 & 3 & 10 & 1 & 3 & - & - & 30 \\
\hline 13 & Y13 & - & - & 9 & 30 & 19 & 63 & 2 & 7 & - & - & 30 \\
\hline 14 & Y14 & 16 & 53 & 14 & 47 & - & - & - & - & - & - & 30 \\
\hline & TOTAL & 187 & $45 \%$ & 166 & $40 \%$ & 61 & $15 \%$ & 6 & $1 \%$ & - & - & 420 \\
\hline
\end{tabular}

Sumber: Data olahan, 2019

Berdasarkan tabel 3 diatas, maka dapat dijelaskan tanggapan responden terhadap Motivasi Kerja Karyawan (Variabel Y) sebagai berikut:

1. Gairah Kerja

a) Dari 30 responden yang memberikan tanggapan tentang pernyataan memiliki semangat dalam bekerja, $22(73 \%)$ responden menyatakan sangat setuju dan 7 (23\%) responden menyatakan setuju.

b) Dari 30 responden yang memberikan tanggapan tentang berusaha melakukan pekerjaan dengan baik $15(50 \%)$ responden menyatakan sangat setuju, 9 (30\%) responden menyatakan setuju dan 6 (20\%) menyatakan ragu-ragu.

c) Dari 30 responden yang memberikan tanggapan tentang mendapat apresiasi dari pimpinan atas pekerjaan yang dilakukan, $8(27 \%)$ responden menyatakan sangat setuju, $10(33 \%)$ menyatakan setuju, 11 (37\%) responden menyatakan ragu-ragu dan 1 (3\%) responden menyatakan tidak setuju.

d) Dari 30 responden yang memberikan tanggapan memiliki perasaan sense of belonging terhadap pekerjaan, $18(60 \%)$ responden menyatakan sangat setuju, $7(23 \%)$ menyatakan setuju dan $1(3 \%)$ responden menyatakan ragu-ragu.

e) Dari 30 responden yang memberikan tanggapan tentang memiliki passion di pekerjaan, 12 $(40 \%)$ responden menyatakan sangat setuju, $16(53 \%)$ responden menyatakan setuju dan 2 (7\%) responden menyatakan ragu-ragu.

2. Daya Penggerak dalam bekerja

a) Dari 30 responden yang memberikan tanggapan tentang memiliki lingkungan kerja yang kondusif, $15(50 \%)$ responden menyatakan sangat setuju dan $15(50 \%)$ responden menyatakan setuju.

b) Dari 30 responden yang memberikan tanggapan memiliki hubungan yang baik dengan rekan kerja, $16(53 \%)$ responden menyatakan sangat setuju, $13(43 \%)$ responden menyatakan setuju dan $1(3 \%)$ responden menyatakan ragu-ragu. 
c) Dari 30 responden yang memberikan tanggapan memiliki pemimpin yang menginspirasi, $7(23 \%)$ responden menyatakan sangat setuju, $9(30 \%)$ responden menyatakan setuju dan $13(43 \%)$ responden menyatakan ragu-ragu

d) Dari 30 responden yang memberikan tanggapan tentang memiliki peluang untuk mengembangkan karir, $13(43 \%)$ responden menyatakan sangat setuju, $13(43 \%)$ responden menyatakan setuju, $3(10 \%)$ responden menyatakan ragu-ragu dan $1(3 \%)$ responden menyatakan tidak setuju.

e) Dari 30 responden yang memberikan tanggapan tentang mendapat pelatihan yang rutin ditempat kerja, $17(57 \%)$ responden menyatakan sangat setuju, 13 (43\%) responden menyatakan setuju.

3. Pendorong karyawan untuk bertindak

a) Dari 30 responden yang memberikan tanggapan tentang melakukan tugas/pekerjaan untuk pengembangan diri, $16(53 \%)$ responden menyatakan sangat setuju, $13(43 \%)$ responden menyatakan setuju, $1(3 \%)$ responden menyatakan ragu-ragu.

b) Dari 30 responden yang memberikan tanggapan merasa memiliki tanggung jawab pribadi untuk menyelesaikan pekerjaan, $12(40 \%)$ responden menyatakan sangat setuju, $14(47 \%)$ responden menyatakan setuju, $3(10 \%)$ responden menyatakan ragu-ragu dan $1(3,3 \%)$ responden menyatakan tidak setuju.

c) Dari 30 responden yang memberikan tanggapan tentang menyelesaikan tantangan pekerjaan untuk mencapai prestasi kerja, 9 (30\%) responden menyatakan setuju dan 19 $(63 \%)$ responden menyatakan ragu-ragu dan $2(7 \%)$ responden menyatakan tidak setuju.

d) Dari 30 responden yang memberikan tanggapan tentang mendapat kepercayaan dari pimpinan untuk menyelesaikan pekerjaan, 16 (53\%) responden menyatakan sangat setuju, $14(47 \%)$ responden menyatakan setuju.

\section{Analisis Hubungan antara Gaya Kepemimpinan Pacesetting (Variabel X) dengan Motivasi Kerja Karyawan (Variabel Y)}

Pengambilan keputusan uji regresi sederhana mengacu pada:

1. Membandingkan dengan nilai signifikansi dengan profitabilitas 0,05

a. Jika nilai signifikansi $<0,05$ artinya variabel bebas $(\mathrm{X})$ berpengaruh terhadap variabel terikat (Y).

b. Jika nilai signifikansi $>0,05$ artinya variabel bebas $(\mathrm{X})$ tidak berpengaruh terhadap variabel terikat (Y).

2. Membandingkan nilai t hitung dengan t tabel

a. Jika nilai $t$ hitung $>t$ tabel artinya variabel $\mathrm{X}$ berpengaruh terhadap variabel $\mathrm{Y}$.

b. Jika nilai $t$ hitung $<\mathrm{t}$ tabel artinya variabel $\mathrm{X}$ tidak berpengaruh terhadap variabel $\mathrm{Y}$.

Berikut ini hasil pengolahan data primer dari hasil kuesioner dengan bantuan program SPSS 20:

Tabel 4: Variables Entered/Removed ${ }^{\mathrm{a}}$

\begin{tabular}{c|c|c|c}
\hline Model & Variables Entered & Variables Removed & Method \\
\hline 1 & Gaya Kepemimpinan Pacesetting & & Enter \\
\hline \multicolumn{2}{c}{ a. Dependent Variable: Motivasi Kerja Karyawan. } \\
b. All requested variables entered.
\end{tabular}

Sumber: Data olahan, 2019

Tabel 4 menjelaskan tentang variabel yang dimasukkan serta metode yang digunakan, dalam hal ini variabel yang dimasukkan adalah variabel Gaya Kepemimpinan Pacesetting sebagai variabel $\mathrm{X}$ dan Motivasi Kerja sebagai variabel $\mathrm{Y}$, metode yang digunakan adalah metode enter. 
Tabel5: ANOVA ${ }^{\mathrm{a}}$

\begin{tabular}{rl|r|r|r|r|r}
\hline Model & & Sum of Squares & df & Mean Square & F & Sig. \\
\hline \multirow{3}{*}{1} & Regression & 248.555 & 1 & 248.555 & 28.729 & $.000^{\mathrm{b}}$ \\
& Residual & 242.245 & 28 & 8.652 & & \\
& Total & 490.800 & 29 & & & \\
\hline
\end{tabular}

a. Dependent Variable: Motivasi Kerja Karyawan

b. Predictors: (Constant), Gaya Kepemimpinan Pacesetting

Sumber: Data olahan, 2019

Tabel 5 menjelaskan bahwa dari output tersebut diketahui nilai $\mathrm{F}$ hitung $=28,729$ dengan tingkat signifikansi sebesar $0,000<0,05$ maka model regresi dapat dipakai untuk memprediksi variabel motivasi kerja karyawan atau dengan kesimpulan bahwa ada pengaruh variabel Gaya Kepemimpinan Pacesetting (X) terhadap Motivasi Kerja Karyawan (Y).

Tabel 6: Coefficients ${ }^{\mathrm{a}}$

\begin{tabular}{|c|c|c|c|c|c|}
\hline \multirow{2}{*}{ Model } & \multicolumn{2}{|c|}{ Unstandardized Coefficients } & \multirow{2}{*}{$\begin{array}{c}\text { Standardized } \\
\text { Coefficients }\end{array}$} & \multirow[t]{2}{*}{$\mathrm{t}$} & \multirow[t]{2}{*}{ Sig. } \\
\hline & $\mathrm{B}$ & Std. Error & & & \\
\hline (Constant) & 33.599 & 4.918 & & 6.832 & .000 \\
\hline $\begin{array}{l}\text { Gaya Kepemimpinan } \\
\text { Pacesetting }\end{array}$ & .657 & .123 & .712 & 5.360 & .000 \\
\hline
\end{tabular}

a. Dependent Variable: Motivasi Kerja Karyawan

Sumber : Data olahan, 2019

Dari tabel 6 diketahui nilai Konstanta (a) Gaya Kepemimpinan Pacesetting adalah 33,599, dan koefisien regresi (b) Motivasi Kerja Karyawan adalah 0,657. Persamaan regresinya dapat ditulis: $\mathrm{Y}=33,599+0,657 \mathrm{X}$, menunjukkan bahwa peningkatan Motivasi Kerja Karyawan ditentukan oleh Gaya Kepemimpinan Pacesetting di FBS Department Sintesa Peninsula Hotel Manado. Konstanta sebesar 33,599, mengandung arti bahwa nilai konsisten variabel Motivasi Kerja adalah sebesar 33,599. Koefisien regresi X sebesar 0,657 menyatakan bahwa setiap penambahan $1 \%$ nilai Gaya Kepemimpinan Pacesetting, maka nilai Motivasi Kerja Karyawan akan bertambah sebesar 0,657. Sebaliknya, jika Gaya Kepemimpinan Pacesetting dikurangi satu-satuan maka akan menurunkan 0,657 satuan motivasi kerja karyawan.

Pengambilan keputusan dalam Uji Regresi Linear Sederhana :

1) Berdasarkan nilai signifikansi dari tabel 6 diperoleh nilai signifikansi sebesar $0,000<0,05$, sehingga dapat disimpulkan bahwa variabel X (Gaya Kepemimpinan Pacesetting) berpengaruh terhadap variabel Y (Motivasi Kerja Karyawan)

2) $\mathrm{t}$ tabel $=(\mathrm{a} / 2 ; \mathrm{n}-\mathrm{k}-1)$

$$
\begin{aligned}
& =(0,05 / 2 ; 30-1-1) \\
& =(0,025 ; 28) \text { lihat pada lampiran distribusi nilai t tabel } \\
& =2,048
\end{aligned}
$$

Berdasarkan nilai t hitung 5,360 > t tabel 2,04841, sehingga dapat disimpulkan bahwa variabel Gaya Kepemimpinan Pacesetting berpengaruh terhadap variabel Motivasi Kerja Karyawan FBS Department.

\section{Koefisien Korelasi Sederhana}

Koefisien Korelasi digunakan untuk mengukur derajat hubungan, meliputi kekuatan hubungan dan bentuk/arah hubungan. Untuk kekuatan hubungan, nilai koefisien korelasi berada diantara 1 dan +1 . Untuk bentuk arah/arah hubungan, nilai koefisien korelasi dinyatakan dalam positif (+) dan negatif $(-)$, atau $(-1 \leq \mathrm{KK} \leq+1)$. 
1) Jika koefisien korelasi bernilai positif maka variabel-variabel berkorelasi positif, artinya jika variabel yang satu naik/turun maka variabel yang lainnya juga baik/turun. Semakin dekat nilai koefisien korelasi ke +1 , semakin kuat korelasi positifnya.

2) Jika koefisien korelasi bernilai negatif maka variabel-variabel berkorelasi negatif, artinya jika yang satu nail/turun maka variabel yang lainnya akan naik/turun. Semakin dekat nilai koefisien korelasi -1, semakin kuat koefisien negatifnya.

3) Jika koefisien korelasi bernilai 0 (nol), maka variabel tidak menunjukkan adanya korelasi

4) Jika koefisien korelasi bernilai +1 atau -1 maka variabel-variabel menunjukkan korelasi positif atau negative sempurna.

Berikut ini hasil pengolahan data primer dari hasil kuesioner dengan bantuan program SPSS 20:

Tabel 7: Perhitungan Korelasi Pearson Product Moment

\begin{tabular}{|c|c|c|c|}
\hline \multicolumn{4}{|c|}{ Correlations } \\
\hline & & Total X & Total Y \\
\hline \multirow{3}{*}{$\begin{array}{c}\text { Gaya Kepemimpinan } \\
\text { Pacesetting }\end{array}$} & Pearson Correlation & 1 & $.712^{* *}$ \\
\hline & Sig. (2-tailed) & & .000 \\
\hline & $\mathrm{N}$ & 30 & 30 \\
\hline \multirow{3}{*}{ Motivasi Kerja } & Pearson Correlation & $.712^{* *}$ & 1 \\
\hline & Sig. (2-tailed) & .000 & \\
\hline & $\mathrm{N}$ & 30 & 30 \\
\hline
\end{tabular}

**. Correlation is significant at the 0.01 level (2-tailed).

Sumber: Data olahan SPSS 20

Rumus persamaan koefisien korelasi

$$
\begin{array}{ll}
\mathrm{n}=30 & \Sigma \mathrm{Y}^{2}=107.772 \\
\Sigma \mathrm{X}=1196 & (\Sigma \mathrm{X})^{2}=1.430 .416 \\
\Sigma \mathrm{Y}=1.794 & (\Sigma \mathrm{Y})^{2}=3.233 .160 \\
\Sigma \mathrm{X}^{2}=48.256 & \Sigma \mathrm{XY}=71.899
\end{array}
$$

$$
\begin{aligned}
& \frac{n\left(\sum X Y\right)-\left(\sum X\right)\left(\sum Y\right)}{\sqrt{\left[n \sum X^{2}-\left(\sum X\right)^{2}\right]\left[n \sum Y^{2}-\left(\sum Y\right)^{2}\right]}} \\
& r=\frac{30(71.899)-(1.196)(1.794)}{\sqrt{\left[30(48.256)-(1.196)^{2}\right]\left[30(107.772)-(1794)^{2}\right]}} \\
& r=\frac{2.156 .970-2.145 .642}{\sqrt{[1.447 .680-1.430 .416][3.233 .160-3.218 .436]}} \\
& r=\frac{11.346}{\sqrt{(111264 t 6(14.724)}} \\
& r=\frac{11.346}{\sqrt{254.195 .136}} \\
& r=\frac{15.943,498}{r} \\
& =0,711638
\end{aligned}
$$

\section{Koefisien determinasi}

Koefisien determinasi digunakan untuk mengetahui besarnya sumbangan sebuah variabel atau lebih (variabel bebas,X) terhadap variasi (naik/turunnya) variabel yang lain (variabel terikat, $\mathrm{Y}$ ) 
1) Jika nilai koefisien determinasi/penentu $(\mathrm{KD})=0$, berarti tidak ada pengaruh variabel independen $(\mathrm{X})$ terhadap variabel dependen $(\mathrm{Y})$.

2) Jika nilai koefisien determinasi $(\mathrm{KD})=1$, berarti variasi (naik/turunnya) variabel dependen adalah $100 \%$ dipengaruhi oleh variabel independen (variabel X).

3) Jika nilai koefisien determinasi $(\mathrm{KD})$ berada diantara 0 dan $1(0<\mathrm{KD}<1)$ maka selebihnya berasal dari faktor-faktor lain.

Untuk mengetahui besarnya pengaruh Gaya Kepemimpinan Pacesetting Terhadap Motivasi Kerja Karyawan dalam bentuk persentase, maka digunakan perhitungan korelasi determinasi dengan rumus sebagai berikut :

$$
\begin{aligned}
\mathrm{KD} & =\mathrm{r}^{2} \times 100 \% \\
& =(0,712)^{2} \times 100 \%
\end{aligned}
$$

Nilai KD $=50,69 \%$

Berdasarkan uji analisis regresi linear sederhana, maka dapat diketahui bahwa persamaan regresi yang diperoleh $\mathrm{Y}=33,599+0,657 \mathrm{X}$, menunjukkan bahwa peningkatan Motivasi Kerja Karyawan ditentukan oleh Gaya Kepemimpinan Pacesetting di FBS Department Sintesa Peninsula Hotel Manado. Konstanta sebesar 33,599, mengandung arti bahwa nilai konsisten variabel Motivasi Kerja adalah sebesar 33,599. Koefisien regresi X sebesar 0,657 menyatakan bahwa setiap penambahan $1 \%$ nilai Gaya Kepemimpinan Pacesetting, maka nilai Motivasi Kerja Karyawan akan bertambah sebesar 0,657. Sebaliknya, jika Gaya Kepemimpinan Pacesetting dikurangi satu-satuan maka akan menurunkan 0,657 satuan Motivasi Kerja Karyawan. Hasil uji regresi linear sederhana juga menyimpulkan bahwa nilai signifikansi sebesar $0,000<0,05$ dan nilai $\mathrm{t}$ hitung 5,360 > t tabel 2,04841, sehingga dapat disimpulkan bahwa variabel Gaya Kepemimpinan Pacesetting berpengaruh terhadap variabel Motivasi Kerja Karyawan FBS Department. Selanjutnya pengaruh antara gaya kepemimpinan pacesetting terhadap motivasi kerja karyawan diketahui, $\mathrm{r}=0,712$ yang termasuk kategori 0,600 - 0,799 memberikan arti bahwa antara Gaya Kepemimpinan Pacesetting dengan Motivasi Kerja Karyawan Food and Beverage Service Department terdapat hubungan positif dan kuat. Diketahui Koefisien Determinasi sebesar 50,69\% memberikan pengertian bahwa terdapat pengaruh yang kuat dari variabel Gaya Kepemimpinan Pacesetting terhadap variabel Motivasi Kerja Karyawan dengan nilai koefisien determinasi tersebut maka selebihnya 49,31\% dipengaruhi oleh faktor-faktor lainnya yang tidak diteliti. Hasil dari penelitian ini mendukung pendapat Kartono (2011) yang mengatakan bahwa gaya kepemimpinan mempunyai pengaruh yang kuat terhadap motivasi sebab keberhasilan seorang pemimpin dalam menggerakkan orang lain untuk mencapai suatu tujuan tergantung pada bagaimana pemimpin itu menciptakan motivasi di dalam diri karyawan. Hasil penelitian ini juga mendukung salah satu penelitian sebelumnya oleh Siswedi (2012) yang menyatakan bahwa terdapat pengaruh yang signifikan dan kuat oleh gaya kepemimpinan terhadap motivasi kerja karyawan pada Dinas Pendidikan Jawa Barat sebesar 42,38 \% dan sisanya 57,62 \% dipengaruhi oleh faktor faktor yang tidak diteliti, angka tersebut diperoleh berdasarkan perhitungan nilai koefisien determinasi dan gaya kepemimpinan afiliatif adalah gaya kepemimpinan yang paling menonjol yang diterapkan oleh pimpinan di Dinas Pendidikan Jawa Barat kepada bawahannya.

\section{SIMPULAN}

Berdasarkan tujuan penelitian dan hipotesis penelitian serta hasil penelitian yang dijabarkan pada Bab IV, hasil uji regresi linear sederhana menyimpulkan bahwa nilai signifikansi sebesar 0,000 $<0,05$ dan nilai $t$ hitung 5,360 $>\mathrm{t}$ tabel 2,04841, sehingga dapat disimpulkan bahwa variabel Gaya Kepemimpinan Pacesetting berpengaruh terhadap variabel Motivasi Kerja Karyawan FBS Department. Gaya kepemimpinan pacesetting memiliki hubungan yang kuat dan berpengaruh positif terhadap motivasi kerja karyawan Food and Beverage Service Department Di Sintesa Peninsula Hotel Manado dengan nilai Koefisien Korelasi $r=0,712$ dan perhitungan Koefisien 
Determinasi sebesar 50,69\% selebihnya sebesar $49,31 \%$ di pengaruhi oleh faktor lainnya yang tidak diteliti. Hipotesis dari penelitian "gaya kepemimpinan pacesetting yang diterapkan seorang pemimpin memiliki pengaruh terhadap motivasi kerja staff/karyawan Food and Beverage Service Department pada Sintesa Peninsula Hotel Manado" dapat diterima. Hasil penelitian ini mendukung pendapat Kartono (2011) yang mengatakan "Gaya kepemimpinan mempunyai pengaruh yang kuat terhadap motivasi kerja karyawan, sebab keberhasilan seorang pemimpin dalam menggerakkan orang lain untuk mencapai suatu tujuan tergantung pada bagaimana pemimpin itu menciptakan motivasi di dalam diri setiap karyawan".Gaya Kepemimpinan yang diterapkan oleh pimpinan Food and Beverage Service Department di Sintesa Peninsula Hotel Manado sudah baik, namun sebagai solusi masalah yang ditemukan dalam penelitian pada Sintesa Peninsula Hotel Manado, maka penulis memberikan rekomendasi sebagai bahan pertimbangan bagi Sintesa Peninsula Hotel Manado. Pemimpin perlu memberikan kesempatan bagi karyawan untuk berinisiatif dalam pekerjaan yang dilakukannya dan lebih fleksibel dalam setiap arahan yang diberikan sehingga karyawan mampu menyelesaikan pekerjaannya dengan baik. Dan untuk meningkatkan motivasi kerja karyawan maka pemimpin perlu untuk menginspirasi karyawan agar dapat bekerja dengan maksimal, memberikan tantangan dalam pekerjaan, dan sanggup mengapresiasi karyawan atas pekerjaan yang telah diselesaikan karyawan.

\section{DAFTAR RUJUKAN}

Anoraga, P., (2009). Manajemen Bisnis. Semarang: PT. Rineka Cipta.

Chukwuma, E. M., \& Obiefuna, O., (2014). Effect of Motivation on Employee Productivity: A Study of Manufacturing Companies in Nnewi. Journal of Managerial Studies and Research 2 (7).

Fahmi, I., (2016). Perilaku Organisasi. Bandung: Alfabeta.

Goleman, D., (2003). Kepemimpinan Yang Mendatangkan Hasil. Cetakan Pertama. Jogjakarta: Amara Books.

Hasibuan, S.P.M., (2016). Manajemen Sumber Daya Manusia. Jakarta: Bumi Aksara. (2013). Manajemen Sumber Daya Manusia. Jakarta: Bumi Aksara. (2007). Manajemen Sumber Daya Manusia. Jakarta: Bumi Aksara.

Kartono, K., (2011). Pemimpin dan Kepemimpinan. Jakarta: Raja Grafindo Persada.

Luthans, F., (2005). Organizational Behavior. $10^{\text {th }}$ edition (terjemahan). Yogyakarta: Andi.

Marchewka, (2015). Information Technology Project Management: Providing Measurable Organizational Value. New Jersey: John Wiley \& Sons Inc.

Molan, B., (2011). Manajemen Eksekutif : Pengembangan Manajer Berprestasi. Jakarta: Indeks. Masaong, K. dan Tilome, A.A., (2011). Kepemimpinan berbasis Multiple Intelligence ( Sinergi Kecerdasan Intelektual, emosional dan Spiritual Untuk Meraih Kesuksesan Yang gemilang). Bandung: Alfabeta.

McShane, L.S dan Von, G., Mary A., (2010). Organizational Behavior. Fourth Edition. United States of America: McGRAW-Hill International.

Pamela, A.O., dan Oloko. (2015). Effect of motivation on employee performance of commercial banks in kenya : A case study of Kenya Commercial Bank in Migori County. Journal of Human Resource Studies.

Robbins, P. Stephen dan Coulter, M., (2005). Manajemen (terjemahan). Jakarta: PT. Indeks Kelompok Gramedia.

Sutikno, M.S., (2014). Pemimpin dan Gaya Kepemimpinan. Edisi Pertama. Lombok: Holistica. Setiawan, A., (2013). Pengaruh Disiplin Kerja dan Motivasi Terhadap Kinerja Karyawan pada Rumah Sakit Umum Daerah Kanjuruhan Malang.Jurnal Ilmu Manajemen.https://jurnalmahasiswa.unesa.ac.id/index.php/jim/article/view/6280/7131. 23 Juni 2019 (11:00). 